\title{
The relationship between parenting style and social development among toddlers in Yogyakarta
}

\author{
Desi Rofita $^{\mathrm{a}, 1^{*}}$, Djauhar Ismail ${ }^{\mathrm{b}, 2}$, Moh. Hakimi ${ }^{\mathrm{c}, 3}$ \\ ${ }^{a}$ Faculty of Health Sciences, Universitas Muhammadiyah Mataram, Jln. KH. Ahmad Dahlan No. 1 Pagesangan, Mataram, West Nusa Tenggara, Indonesia \\ b,c Gadjah Mada University, Bulaksumur, Caturtunggal, Depok, Sleman, Yogyakarta Special Region, 55281, Indonesia \\ ${ }^{1}$ desirofita21@gmail.com*; ${ }^{2}$ djauharisml@yahoo.co.id; ${ }^{3}$ moh.hakimi@yahoo.com \\ * Corresponding author
}

ARTICLE INFO

Article history

Received, $3^{\text {th }}$ February 2021

Revised, $31^{\text {st }}$ August 2021

Accepted, $14^{\text {th }}$ April 2021

Keywords

Mother Parenting

Social Development

Preschoolers

\section{ABSTRACT}

Background: The development of children at preschool age is mentioned as the "Golden Period." At this time, the development of creativity, social awareness, emotional, and intelligence goes swiftly, therefore the parenting provided by parents from an early age will affect the future child's development

Purpose: the major aim of the study was to know the relationship between parenting style and social development among toddlers in Yogyakarta

Methods: The design of this research was observational analytic with a cross-sectional design. The subjects of this study were mothers who have children aged 4-6 years, the sample used was 50 respondents. Data were analyzed using the chi-square test. An instrument using VSMS (Vineland Social Maturity Scale).

Results: The results of the statistical test revealed that authoritarian parenting risked the children's social development by 5.5 times compared to authoritarian parenting, while permissive parenting risked children's social development by 7,5 times compared to authoritarian parenting. There is a significant relationship between parenting and social development of children with the value of CI 95\% $=1.298-41.420(p=$ 0.02 ). While the mothers' age does not have a significant relationship with the children's social development ( $\mathrm{p}$-value $=0.07$ ), as well as the mothers' employment status does not have a significant relationship with the child's social development ( $p$-value $=0.13$ ).

Conclusion: This study shows that there is a significant relationship between parenting and the social development of children, however, there is no significant relationship between age and mothers' employment status on children's social development. Authoritarian parenting is the most effective parenting approach to children's social development compared to authoritarian and permissive parenting.

This is an open access article under the $\mathrm{CC}-\mathrm{BY}$-SA license.

\section{Introduction}

The World Health Organization (WHO) reports that 5-25\% of preschool children suffer from minor brain dysfunction, including developmental disorders (Lucas-Thompson, R. G., Lunkenheimer, E. S., Dumitrache, 2017) . In 2016 there were 250 million children, or 43\%, children aged 0-8 in low and middle-income countries who were unable to realize the full potential of Early Child Development which includes physical, social-emotional, cognitive development and motor. Neuro-scientific evidence is growing rapidly and by 2016, new evidence has become available regarding the burden of children at risk of underdevelopment (Houtrow et al., 2012). 
Data from the Indonesian Pediatric Association (IDAI) in 2013, it is estimated that 5-10\% of children experience developmental delays and it is estimated that around 1-3\% of children under the age of 5 experience general developmental delays. The results of the 2013 Riskesdas, mentalemotional disorders in Indonesia were $6 \%$ and Yogyakarta province had a prevalence of mentalemotional disorders of 8.1\% (Depkes-RI, 2012). Meanwhile, the results of Riskesdas 2018 show that mental-emotional disorders in Indonesia are 9.8\%, and Yogyakarta province has a prevalence of emotional mental disorders of $10 \%$. This shows an increase in the prevalence of mental-emotional disorders during the last 5 (Hosokawa \& Katsura, 2017).

The development of children at preschool age is known as the golden period or "Golden Period", which means that the development at this age is very influential on the development in the next period until the child becomes an adult. Positive indicators of children's psychosocial well-being during early and middle childhood have been shown to be inversely related to depression, hostile behavior, and other aggressive interpersonal behavior (Jaafar \& Bilyk, 2013).

Physical activity behavior develops during the childhood period ( $0-5$ years) and impacts a variety of health and development outcomes, including psychosocial well-being. Social skills are one of the components related to the psychosocial well-being of children, so this component is very important for the mental health of children in the future (Hinkley et al., 2018). Empirical evidence proves that early childhood development is very important for one's physical health (Campbel et al., 2014).

The factors that influence children's development are family income because lower income in the household can hinder children's development (Boca et al., 2016). The second is the number of children in a family because more children in the household can damage the relationship between parenting skills and the development of children with siblings (Zhong et al., 2020). The third is the level of parental education because parents with undergraduate education tend to use democratic parenting compared to parents with lower levels of education (Boediman \& Desnawati, 2019).

Children with more self-control (aspects of self-regulation) are more likely to grow up to be adults with better health (for example, better physical health, less substance abuse), have higher incomes and less financial difficulties, and fewer criminal penalties than those with weaker selfregulation skills (Moffitt et al., 2011).

Social and emotional development is the emerging ability of children (ages 0-5) to form close and safe adult and peer relationships, experiences, and express emotions in socially and culturally appropriate ways, and to explore the environment and learning in the context of family, community, and culture (Janus \& Moerschel, 2010). A good social function can influence academic development stronger (Arnold et al., 2012).

Children as an aspect of child development cannot actually be separated from one another. In other words, discussing emotional development must intersect with children's social development. Children with emotional disorders or disruptive behavior have various possible risks, including: inhibiting children's participation in educational activities, keeping children away from peers, harming children and other friends physically, affecting the continuity of the learning process and other individual functions in the classroom, reducing children's opportunities to be involved in community activities, as well as a high risk of increasing delinquency and crime in adulthood (Claessens \& Dowsett, 2014).

In Kindergarten, there are several emotional problems or emotional disorders that commonly occur in Kindergarten age children, namely aggressiveness, anxiety, tantrums, withdrawal, enuresis and encopresis, lying, excessive crying, dependence, shyness, and afraid of exaggeration. These types of disorders in the realm of emotional disorders that often arise include: aggressiveness, anxiety, temper tantrums, withdrawal, excessive fear, lack of affection, and hypersensitivity so that they affect children's mental health (Mirzaee et al., 2015)

Children's social skills are important indicators in the development of their school readiness and peer acceptance. Therefore, parents ensure their children have sufficient opportunities to develop and practice their social skills so that they can form the foundation of long-term health and well-being (Hinkley et al., 2018). 
The emergence of social and emotional skills begins at birth and early experiences influence how children begin to understand the world and themselves. Therefore, parents play an important role in influencing children's development. Parents who are able to regulate emotions and pay more attention to their environment can develop safe relationships with children (Eisenberg et al., 2010). Emotional regulation in children does not develop automatically. Early in life, children need a lot of support and guidance from parents to regulate their emotions. Through supportive interactions with parents, children learn how to deal with uncomfortable situations (Jabeen et al., 2013).

Parenting is the way parents interact with their children. Some parenting styles that can be done to be applied in a parenting sytle are; authoritarian, permissive and democratic. This system of care must be adapted to the needs of the family because it will have an impact on the development of the child. Some children who are raised in different environments can have similar personalities. On the other hand, children who live in the same house and are raised in the same environment can have very different personalities (Dalwood et al., 2020).

Parenting styles are the attitudes and behaviors of parents that can shape the emotional climate in which parents raise their children. Parents play an important role in the social and emotional development of children. For example, affective and warm parenting (i.e., responsiveness, support, and parental involvement), as well as behavioral controls implemented by parents have been shown to reduce behavioral problems in children (Aunola et al., 2015). Social and emotional experiences with positive parenting can influence a child's future academic and personal outcomes, and underpin other areas of development (Denham \& Brown, 2010).

\section{The Proposed Method}

The major aim of the study to know the relationship between parenting style and social development among toddlers in Yogyakarta

\section{Method}

This research is a quantitative study using an analytic observational research design, using a cross-sectional approach. The research was conducted was conducted at one of kindergarten in Yogyakarta starting in December 2019. The research variables consisted of independent variables (parenting styles), dependent variables (children's social development), and external variables (parental education, age of parents, the gender of children, number of children, employment status, Companion Caregivers). The population in this study was 104 children with a total sample size of 50 children according to the inclusion and exclusion criteria. The sampling technique was purposive sampling. The research instrument used the Parenting Styles and Dimensions Questionnaire (PSDQ) (Kern \& Jonyniene, 2012)to measure parenting styles and was the VSMS (Vineland Social Maturity Scale). data analysis using chi-square. Ethical Clearance was conducted at the Institute for Research and Community Service Development (LP3M) Universitas 'Aisyiyah Yogyakarta No.933/KEPUNISA/XI/2019. 


\section{Results and Discussion}

\subsection{Characteristic Respondents}

Table 1. Frequency distribution of respondent characteristics

\begin{tabular}{ccc} 
Characteristics & n & \% \\
\hline $\begin{array}{c}\text { Mother characteristics } \\
\text { Mother's age }\end{array}$ & \\
Early adulthood (21-40 years) & 28 & 56,0 \\
Middle adult (41-60 years) & 22 & 44,0 \\
Mother's education & 45 & 90,0 \\
High (SMA, D3 / PT) & 5 & 10,0 \\
Low (did not complete SD, SD, SMP, SMA) & & \\
Mother's Work Status & 22 & 56,0 \\
Does not work & 28 & 44,0 \\
Work & & \\
Companion Caregivers & 17 & 34,0 \\
Grandma / other family members & 6 & 12,0 \\
Baby sisters & 27 & 54,0 \\
Without a companion nanny & & \\
Number of children & 39 & 78,0 \\
1-2 people & 11 & 22,0 \\
$\geq 3$ people & & \\
Toddler characteristics & 10 & 20,0 \\
Age & 29 & 58,0 \\
4 years & 11 & 22,0 \\
5 years & & \\
6 years & & \\
Gender & 23 & 54,0 \\
Male & & 56,0 \\
Female & 27 & \\
\hline & & \\
\hline
\end{tabular}

\subsection{Data Analysis}

a) Univariate Analysis

Table 2 shows that the majority of mothers apply democratic parenting, as many as 39 people (78\%) and 38 people (76\%) have children with good social development.

Table 2. Frequency Distribution of Mother's Parenting Patterns to Children's Social Development

\begin{tabular}{cccc}
\hline Variable & Characteristics & $\mathbf{n}$ & $\%$ \\
\hline Variable & Authoritative & 39 & 78,0 \\
& Authoritarian & 4 & 8,0 \\
& Permissive & 7 & 14,0 \\
Child Social Development & Good & 38 & 76,0 \\
& Not Good & 12 & 24,0 \\
\hline
\end{tabular}

b) Bivariate Analysis

1) The relationship between parenting and social development of preschool children

Table 3 shows the relationship between parenting and social development of preschool children.

Table 3. The relationship between parenting and social development of preschool children

\begin{tabular}{|c|c|c|c|c|c|c|c|c|c|}
\hline \multirow{3}{*}{ Variable } & \multicolumn{4}{|c|}{$\begin{array}{l}\text { Child Social } \\
\text { Development }\end{array}$} & \multirow{2}{*}{\multicolumn{2}{|c|}{ Total }} & \multirow{3}{*}{$\underset{\text { Value }}{p}$} & \multirow{3}{*}{ PR } & \multirow{3}{*}{ CI $95 \%$} \\
\hline & \multicolumn{2}{|c|}{ Good } & \multicolumn{2}{|c|}{ Not Good } & & & & & \\
\hline & $n$ & $\%$ & $n$ & $\%$ & $N$ & $\%$ & & & \\
\hline Parenting & & & & & & & & & \\
\hline Authoritative & 33 & 84,6 & 6 & 15,4 & 39 & 100 & $0,02 *$ & & \\
\hline Authoritarian & 2 & 50 & 2 & 50 & 4 & 100 & & 5.5 & $0.644-46.949$ \\
\hline Permissive & 3 & 42,9 & 4 & 57,1 & 7 & 100 & & 7.3 & $1.298-41.420$ \\
\hline
\end{tabular}


Based on table 3, it can be seen that authoritarian parenting risked the children's social development by 5.5 times compared to authoritative parenting, while permissive parenting risked children's social development by 7,5 times compared to authoritative parenting. There is a significant relationship between parenting and social development of children with the value of CI 95\% = 1.298-41.420 $(\mathrm{p}=0.02)$.

2) Relationship of external variables with the social development of preschool children.

Table 4 shows that most mothers with higher education have children with good social development, as many as $33(73.3 \%)$ and $12(26.6 \%)$ children with poor social development.

Table 4. Relationship of external variables with the social development of preschool children.

\begin{tabular}{|c|c|c|c|c|c|c|c|c|c|}
\hline \multirow{3}{*}{ Variable } & \multicolumn{4}{|c|}{ Child Social Development } & \multirow{2}{*}{\multicolumn{2}{|c|}{ Total }} & \multirow{3}{*}{$\underset{\text { Value }}{p}$} & \multirow{3}{*}{$\mathbf{P R}$} & \multirow{3}{*}{ CI 95\% } \\
\hline & \multicolumn{2}{|c|}{ Good } & \multicolumn{2}{|c|}{ Not Good } & & & & & \\
\hline & $\mathrm{n}$ & $\%$ & $n$ & $\%$ & n & $\%$ & & & \\
\hline \multicolumn{10}{|l|}{ Mother's education } \\
\hline High & 5 & 100 & 0 & 0 & 5 & 10,0 & 0,99 & 4,10 & 0,00 \\
\hline Low & 33 & 73,3 & 12 & 26,6 & 45 & 100 & & & \\
\hline \multicolumn{10}{|l|}{ Mother's age } \\
\hline Early adulthood & 24 & 85,7 & 4 & 14,2 & 28 & 100 & & & \\
\hline Middle adult & 14 & 63,6 & 8 & 36,3 & 22 & 100 & $0,07 *$ & 3,42 & $0,872-13,483$ \\
\hline \multicolumn{10}{|l|}{ Mother's Work Status } \\
\hline Unemployed & 19 & 86,3 & 3 & 13,6 & 22 & 100 & $0,13^{*}$ & 3,00 & $0,701-12,830$ \\
\hline Employed & 19 & 67,8 & 9 & 32,1 & 28 & 100 & & & \\
\hline \multicolumn{10}{|l|}{ the gender of the child } \\
\hline Male & 16 & 69,5 & 7 & 30,4 & 23 & 100 & 0,32 & 0,51 & $0,139-1,937$ \\
\hline Female & 22 & 81,4 & 5 & 18,5 & 27 & 100 & & & \\
\hline \multicolumn{10}{|l|}{ Number of children } \\
\hline 1-2 people & 29 & 74,3 & 10 & 25,6 & 39 & 100 & 0,61 & 0,64 & $0,119-3,501$ \\
\hline$\geq 3$ people & 9 & 81,8 & 2 & 18,1 & 11 & 100 & & & \\
\hline \multicolumn{10}{|l|}{ Companion Caregivers } \\
\hline $\begin{array}{c}\text { Grandma / other family } \\
\text { members }\end{array}$ & 13 & 76,4 & 4 & 23,5 & 17 & 100 & 0,65 & 0,73 & $0,128-2,940$ \\
\hline Baby sisters & 6 & 100 & 0 & 0 & 6 & 100 & & & \\
\hline $\begin{array}{c}\text { Without a companion } \\
\text { nanny }\end{array}$ & 17 & 62,9 & 8 & 29,6 & 27 & 100 & & & \\
\hline
\end{tabular}

From the analysis, it was obtained that the value of CI 95\% $=0.00$ (p-value 0.99). There is no significant relationship between maternal education and the social development of preschool children. The majority of mothers aged $<40$ years have children with good social development with a total of $24(85.7 \%)$ and $4(14.2 \%)$ who are not. Maternal age 41 years has a 3.5 times risk of developing social development disorders in preschool children compared to mothers with age $<41$ years (PR 3,429). There is no significant relationship with the social development of preschool children. This can be seen from the results of statistical tests that the CI value of $95 \%=0.872-13.483$ (p-value 0.07 ).

The majority of mothers aged $<40$ years have children with good social development as many as $24(85.7 \%)$ and poor social development as many as $4(14.2 \%)$. Maternal age $>41$ years has a 3.5 times risk of developing social development disorders in preschool children compared to mothers with age $<41$ years (PR 3,429). There is no significant relationship with the social development of preschool children. This can be seen from the results of statistical tests that the value of CI 95\% $=0.872-13.483$ (p-value 0.07 ).

The results of statistical tests showed that mothers with working status had three times the risk of developing social development disorders in preschool children compared to mothers with non-working status ( $\mathrm{PR}=3,000)$. There is no significant relationship between work status and social development of preschool children seen from the value of CI $95 \%=$ $0.701-12.830(\mathrm{p}$-value $=0.13)$.

Other variables that have no relationship with the social development of pre-school children are the sex of the child with the value of CI 95\% $=0.139-1.937$ ( $p$ value $=0.32)$, the number of children with the value of CI 95\% $=0.119-3.501$ ( $\mathrm{p}$ value $=0,61$ ), and 
accompanying caregivers with the value of CI 95\% $=0.128-2.940(\mathrm{p}$ value $=0.65)$ because the value of $\alpha>0.05$.

c) Multivariate Analysis

Three variables meet the requirements $(p<0.25)$ to be continued in the multivariate analysis, namely variables of maternal parenting, mother's age, and mother's employment status on the social development of children under five, while the gender of the child, the number of children, and accompanying caregivers are not analyzed. multivariate because $\mathrm{p}$ value $>0.25$. The results of the multivariate analysis can be seen in table 5 .

Table 5. Result of Multivariate Analysis

\begin{tabular}{|c|c|c|c|c|}
\hline Variable & $\begin{array}{c}\text { Model 1 } \\
\text { PR }(\text { CI } 95 \%)\end{array}$ & $\begin{array}{c}\text { Model } 2 \\
\text { PR }(\text { CI } 95 \%)\end{array}$ & $\begin{array}{c}\text { Model 3 } \\
\text { PR }(\text { CI } 95 \%)\end{array}$ & $\begin{array}{c}\text { Model } 4 \\
\text { PR }(\text { CI } 95 \%)\end{array}$ \\
\hline \multicolumn{5}{|l|}{ Parenting } \\
\hline \multicolumn{5}{|l|}{ Authoritative } \\
\hline \multirow[t]{2}{*}{ Authoritarian } & 5.50 & 5.32 & 13.139 & 11.467 \\
\hline & $(0.644-46.949)$ & $(0.585-48.453)$ & $(0.997-173.114)$ & $(0.839-156.659)$ \\
\hline \multirow[t]{2}{*}{ Permissive } & 7.33 & 5.77 & 10.006 & 8.117 \\
\hline & $(1,298-41,420)$ & $(0,967-34.467)$ & $(1,413-70.876)$ & (1.061-62.087) \\
\hline \multicolumn{5}{|l|}{ Mother's age } \\
\hline \multicolumn{5}{|l|}{ Early adulthood } \\
\hline \multirow[t]{2}{*}{ Middle adult } & & 2.722 & & 1.853 \\
\hline & & $(0,628-11,792)$ & & $(0,388-8,842)$ \\
\hline \multicolumn{5}{|c|}{ Mother's Work Status } \\
\hline \multicolumn{5}{|c|}{ Unemployed } \\
\hline \multirow[t]{2}{*}{ Employed } & & & 5.742 & 8.842 \\
\hline & & & $(0.897-36.735)$ & $(0,703-31.167)$ \\
\hline R2 & 0,183 & 0,230 & 0,291 & 0,305 \\
\hline $\mathbf{N}$ & 50 & 50 & 50 & 50 \\
\hline
\end{tabular}

Model selection is done by looking at the value highest $\mathrm{R}^{2}$ value, which is model 4 with an $\mathrm{R}^{2}$ value of 0,305 , which means that parenting, mother's age, and mother's work status contribute to children's social development $30.5 \%$, the remaining $69.5 \%$ is caused by variables other. Maternal parenting has a PR value of 8.117 (CI 95\% = 1.061-62.087), meaning that permissive parenting has the opportunity to develop social development disorders in children. Maternal age did not have a significant relationship with the social development of preschool children $(\mathrm{CI}$ 95\% $=0.388-8.842)$ as well as employment status did not have a significant relationship with the social development of preschool children (CI 95\% $=0.703-31.167)$.

\subsection{Parenting Styles}

Parenting styles in this study are divided into three, including authoritative (democratic), authoritarian (authoritarian), and permissive (permissive) parenting styles. This is in accordance with research conducted by Boediman \& Desnawati, (2019) which divides parenting styles into three, including: authoritarian, authoritative, and permissive parenting.

The results of the study as shown in Table 4.2 show that most mothers applied authoritative parenting to their children, as many as 39 people $(78.0 \%)$, which means that this parenting is a positive parenting style for children's social development. This is consistent with research conducted by Zhong et al., 2020 which states that positive parenting skills have a significant relationship with cognitive, language, motor and social-emotional development of children, and the relationship between parenting skills and social development. emotional is the strongest.

Parenting plays an important role in early childhood development. Different parenting styles provide different benefits for children's development. Parent-child interactions such as providing stimulation are able to produce positive social development for children because responsive parents will build good children's social development. Children tend to increase their engagement with the environment when mothers learn to adapt to their child's needs (Augustine et al., 2015).

Poor parenting patterns are highly correlated with developmental delays in childhood (Luo et al., n.d.). Therefore, a positive parenting style is needed to support the development of a child's 
development because good parenting can reduce children's health risks (for example, by reducing stress, avoiding exposure to infection, or reducing the chance of injury) resulting in fewer illnesses and reduced needs. children going to health care (Serbin et al., 2014).

Parenting skills during the early stages of childhood can be important for the achievement of social-emotional skills in the future (Barbara Gross Davis, 2009). Avoidance of negative things from parents such as reducing spanking, emotional control, or rude behavior of parents can improve children's academic skills and behavior (Ansari \& Gershoff, 2016). The warmth that exists between parent-child can reduce problems with child development because different parenting styles can bring different benefits to children, this is evident in developed countries (Zheng \& McMahon, 2019).

Support provided by parents refers to the capacity of parents to be aware of and responsive to the circumstances, needs, and goals of their children. Great parental support has been associated with positive outcomes for children's social competence and psychosocial functioning. Supportive parents can create an emotionally safe environment, where children are encouraged to express their health needs and complaints (Qi, 2017).

In Asian (including Indonesian) cultures, authoritarian parenting can be associated with parental care, attention, love and support. However, this study reveals that the majority of parents in Indonesia apply authoritative parenting, which is the parenting style most often adopted by parents in Western culture. This kind of parenting is different from the values commonly practiced by most Indonesian parents (Boediman \& Desnawati, 2019).

\subsection{Social Development of Children}

Social development in this study is divided into two categories, namely social development in the good category of 38 children and social development in the bad category of 12 children. Positive social emotional development makes it easier for children to get along with others and learn better, as well as in other activities in the social environment. When children enter the play group, they begin to leave the family environment and enter a new world. Children's routines play an important role in children's socio-emotional development (Ren et al., 2019).

Social skills acquired through social interaction can support children's social development. children who have good social development often use these skills in interpersonal relationships and everyday life. Children with poor social skills will face various problems throughout their life such as interpersonal relationships, academic studies, emotional behavior and in other professional lives (Tatli \& Pirpir, 2015).

Social and emotional competence are closely related to children's readiness to enter the school environment. Research shows that social skills and accompanying process skills (e.g., attention and learning approaches) that are evident at school (i.e. around age 5) are the best predictors of later social and emotional competence, such as managing behavior, making social relationships, and tolerate frustration with peers (Halle et al., 2012). Certain social and emotional problems such as anxiety and depression also have a negative impact on children's academic achievement later in life (Romano et al., 2010).

In this study, the measuring instrument used to measure children's social development is the VSMS (Vineland Social Maturity Scale). The aspects measured include self-help, (self-direction), motion (locomotion), work (occupation), socialization (socialization), communication (communication). VSMS (Vineland Social Maturity Scale) is the most effective tool for measuring the social maturity of children in particular.

This is supported by research conducted (Raposa et al., 2014) on the social maturity of preschool children using the VSMS (Vineland Social Maturity Scale) measurement tool to measure children's social maturity. The same research was conducted (Perna et al., 2010) which measures the social maturity of early childhood using the VSMS (Vineland Social Maturity Scale) measurement tool. 


\subsection{Parenting Style with Child Social Development}

This study shows that of the 50 respondents who apply democratic parenting as many as 39 people with good social development of children as many as 33 and social development of children who are not good as many as 6 . Respondents with authoritarian parenting are 4 people with good social development of children as many as 2 and poor social development of 2 children, and 7 respondents with permissive parenting, 3 with good social development and 4 children with poor social development.

Based on the results of statistical tests, it can be seen that authoritarian parenting has a risk of social development of children 5.5 times compared to democratic parenting and permissive parenting has a risk of social development of children 7.5 times compared to democratic parenting. There was a significant relationship between parenting styles and children's social development with a 95\% CI value $=1.298-41.420(\mathrm{p}=0.02)$. This is consistent with research conducted by Saltali, N. D. \& Arslan, E. (2012) which states that parenting has a significant relationship with children's social development. Lack of maternal love for children can affect the child's social development (Zarra et al., 2014).

Parenting style has an influence on children's social development. Authoritarian parenting (strict rules, strength, threats, verbal and physical punishment) results in anti-social behavior (Mensah \& Kuranchie, 2013). Similar research also says that authoritarian parenting shows more negative results such as hyperactive children, behavioral problems, and emotional symptoms compared to other parenting styles (Sels et al., 2016). A number of studies conducted in Western culture on parenting styles show that children with authoritative parenting tend to function well (psychologically, socially, and academically) (Rinaldi \& Howe, 2012).

Parents with permissive parenting tend to spoil their children, lacking the direction and guidance for the child necessary to develop proper morals and goals (Bornstein \& Bornstein, 2014). Children with indulgent / permissive parents tend to have good social skills and self-confidence but exhibit inappropriate behavior and engage in drug and alcohol use (Fletcher et al., 2010). Parents who apply permissive and authoritarian parenting have a negative impact on the child's psychology. Children from authoritarian families are highly incompetent and unable to adapt. Heavy physical punishment and arbitrary discipline can harm children because it will have a negative impact on children's development (Baumrind et al., 2013).

The most important thing in the process of social development is family, namely parents and siblings. The quality of the relationship between parents and children is very important and influences children's development (Simkiss, 2013). Parents who apply democratic parenting influence children's social skills positively and significantly, while parenting parents who are too protective can negatively and significantly affect children's social development (Kol, 2016).

A flexible and warm parenting style is the most beneficial for a child's social, intellectual, moral and emotional growth (Bornstein \& Bornstein, 2014). Regular family routines, such as eating together or reading together, provide opportunities for children to bond with their parents and build closer family relationships (Ren et al., 2019). Optimal care provided by parents is important for children with greater externalization problems in childhood because it affects the quality of the child's socio-emotional development (Ball et al., 2016).

\subsection{Maternal Age with Child Social Development}

The results showed that there was no significant relationship with the social development of preschool children. This can be seen from the results of statistical tests that the age of mothers $>41$ years has a 3.5 times risk of social development disorders compared to mothers with age $<41$ years (PR 3,429). There is no significant relationship with the social development of children. This can be seen from the results of statistical tests that the value of CI 95\% $=0.872-13.483$ (p-value 0.07).

Parents too young or old may not be able to carry out this role optimally because it requires physical and psychological strength. Young parents are more likely to apply democratic and 
permissive parenting to their children because they are more open and able to communicate well. Meanwhile, older couples are more likely to apply authoritarian parenting to their children because they feel more experienced in providing care for their children (Ering et al., 2014).

Research conducted by (Augustine et al., 2015) states that delaying the first birth after adolescence allows mothers to complete more schooling, start careers, and gain a number of other experiences that can contribute to their child's postnatal environment. With these experiences, a mother has a lot of knowledge related to how to educate her child properly so that it can affect the child's future development

Similar research also says that maternal age is associated with delayed child birth. Young mothers will delay the birth of their first child compared to older mothers so that young mothers have the opportunity to complete education, and have plenty of time to learn to be good mothers. Delayed first birth is beneficial for children's development (Duncan et al., 2018).

Another study showed that the relationship between parental age and child development shows an inverted U-shape. Thus it turns negative at the advanced age of the mother. Older parents have worse physical condition than younger parents when it comes to parenting (Leigh \& Gong, 2010).

\subsection{Mother Work Status with Child Social Development}

The results of statistical tests showed that mothers with working status had three times the risk of social development disorders compared to mothers with non-working status ( $\mathrm{PR}=3,000)$. There is no significant relationship between work status and social development of preschool children seen from the value of CI 95\% $=0.701-12.830(\mathrm{p}$-value $=0.13)$.

This is in accordance with research conducted by (Zhong et al., 2019) which states that there is no significant relationship between work status and children's social development. Another study conducted by (Lombardi \& Coley, 2017) said that working mothers spend more time at work than caring for their children so that it affects children's behavioral functions. Maternal work is associated with the time spent caring for the child, the hours of care and the type of quality child care that affects child development (Brooks-Gunn et al., 2010).

The existence of sufficient quality time to be with children in playing and providing adequate stimulus for toddlers, both working and non-working mothers (housewives) is one of the determinants of whether or not child development is good (Mensah \& Kuranchie, 2013). Research by (Nezhad, 2013; Saltalı \& Arslan, 2012) found that time investment from non-working mothers in their involvement with children has a positive effect on children's emotional social development. Another study conducted by (Sels et al., 2016) found a negative relationship between maternal work and cognitive development and children's social development

The negative impact of working mothers on child development is that children can be emotionally disturbed, creating negative attitudes that have a negative effect on children's social, psychological and emotional development (Ball et al., 2016). This is because the mother may feel too overwhelmed and tired of trying to balance work and family (Boca et al., 2016). If mothers bring their frustrations home it will impact the children as mothers are not enthusiastic about hearing their children's problems after a busy day at work resulting in children looking for solutions elsewhere or simply feeling that their parents are not interested in their lives (Singh, 2018).

\section{Conclusion}

There is a significant relationship between parenting and social development of toddlers in Yogyakarta. Authoritative parenting is more effective in children's social development than authoritarian and permissive parenting. The majority of mothers applied democratic parenting compared to authoritarian parenting and permissive parenting, as many as 39 people (78\%). There were 38 children $(76 \%)$ with good social development and 12 children (24\%) with poor social development. 


\section{Acknowledgments}

The author would like to thank the supervisor and respondents, so that the author can complete the preparation of this research

\section{References}

Ansari, \& Gershoff. (2016). Parent involvement in head start and children's development: Indirect effects through parenting. J. Marriage Fam, 78(1), 562-579.

Arnold, Kupersmidt, Voegler-Lee, \& Marshall. (2012). The association between preschool children's social functioning and their emergent academic skills. Early Child. Res. Q.

Augustine, Prickett, Kendig, \& Crosnoe. (2015). Maternal education and the link between birth timing and children's school readiness. Social Science Quarterly, 96(1), 970-984.

Aunola, Ruusunen, Viljaranta, \& Nurmi. (2015). Parental affection and psychological control as mediators between parents' depressive symptoms and child distress. Journal of Family Issues, 36(1), 1022-1042.

Ball, M., Weaver, C., \& ... (2016). Healthcare Information Management Systems. In Journal of Information Systems Education (Vol. 14, Issue 4). https://doi.org/10.1007/978-3-319-20765-0

Barbara Gross Davis. (2009). Tools for Teaching. Jossey-Bass.

Baumrind, Arzelere, Owens, Baumrind, Larzelere, \& Owens. (2013). Effects of Preschool Parents' Power Assertive Patterns and Practices on Adolescent Development Effects of Preschool Parents' Power Assertive Patterns and Practices on Adolescent Developmen.

Boca, D., Flinn, \& Wiswall, M. (2016). Transfers to households with children and child development. Econ. J., 126(1), F136-F183.

Boediman, \& Desnawati. (2019). The Relationship between Parenting Style and Children's Emotional Development among Indonesian Population. Jurnal Ilmiah Psikologi, 10(1), 17-24.

Bornstein, \& Bornstein. (2014). Parenting Styles and Child Social Development 3.

Brooks-Gunn, Han, \& Waldfogel. (2010). Firstyear maternal employment and child development in the first 7 years. Monographs of the Society for Research in Child Development, 75(2).

Campbel, Conti, Heckman, Moon, Pinto, Pungello, \& Pan. (2014). Early childhood investment substantially boost adult health. Science, 343(1), 1478-1485.

Claessens, \& Dowsett. (2014). chGrowth and Change in Attention Problems, Disruptive Behavior, and Achievement from Kindergarten to Fifth Grade. Early Childhood Social and Emotional Development: Advancing the Field of Measurement. Journal of Applied Developmental Psychology, 25(12), 2241-2251.

Dalwood, P., Marshall, S., Burrows, T. L., McIntosh, A., \& Collins, C. E. (2020). Diet quality indices and their associations with health-related outcomes in children and adolescents: an updated systematic review. European Journal of Nutrition, 19(1). doi: 10.1186/s12937-020-00632-x.

Denham, \& Brown. (2010). "Plays nice with others": Social-emotional learning and academic success. Early Education \&Development, 21(1), 652-680.

Depkes-RI. (2012). Health Profile of Republic of Indonesia.

Duncan, Kenneth, Lee, \& Rosales-Rueda, M. (2018). Maternal Age and Child Development. Physiology \& Behavior. 176(1), 139-148.

Eisenberg, Spinrad, \& Eggum. (2010). Emotion-related self-regulation and its relation to children's maladjustment. Annual Review of Clinical Psychology, 6, 495-525. 
Ering, Akpan, \& Emma-Echiegu. (2014). Mothers Employment Demands and Child Development: An Empirical Analysis of Working Mothers in Calabar Municipality. American International Journal of Contemporary Research, 4(1), 184-191.

Fletcher, Walls, Cook, \& Madison. (2010). Parenting style as a moderator of associations between maternal disciplinary strategies and child well-being. Journal of Family Issues, 29, 1724.

Halle, Hair, Burchinal, Anderson, \& Zaslow. (2012). In the running for suc-cessful outcomes: Exploring the evidence for thresholds ofschool readiness. Technical report (Retrieved from Office of the Assistant Secretary for Planning and Evaluation, U.S. Department of Health and Human.

Hinkley, Brown, Carson, \& Teychenne. (2018). Cross sectional associations of screen time and outdoor play with social skills in preschool children. 13(4).

Hosokawa, R., \& Katsura, T. (2017). A longitudinal study of socioeconomic status, family processes, and child adjustment from preschool until early elementary school: the role of social competence. Child and Adolescent Psychiatry and Mental Health. 11(1). https://doi.org/10.1186/s13034-017-0206-z

Houtrow, A., Jones, J., Ghandour, R., Strickland, B., \& Newacheck, P. (2012). articipation of Children with Special Health Care Needs in School and the Community. Academic Pediatrics. 12(4), 326-334. https://doi.org/10.1016/j.acap.2012.03.004

Jaafar, \& Bilyk. (2013). The Journal of Social Social Skills , Friendship and Happiness : A CrossCultural Investigation. The Journal of Social Psychology, 2(1), 27-41.

Jabeen, Anis-ul-Haque, \& Riaz. (2013). Parenting styles as predictors of emotion regulation among adolescents. Pakistan Journal of Psychological Research, 28(1), 25-105.

Janus, J., \& Moerschel, S. K. (2010). Evaluation of Anemia in Children. American Family Physician. 81(12), 1462-1471.

Kern, \& Jonyniene. (2012). Psychometric properties of the Lithuanian version of the parenting style and dimensions questionnaire (PSDQ): Pilot study. The Family Journal Counseling and Therapy for Couples Dan Families, 20(2), 205-214.

Kol. (2016). The Efects off The Parenting Styles On Social Skills Of Children Aged 5-6. 4(2), 49-58.

Leigh, \& Gong. (2010). Does maternal age affect children's test scores? Australian Economic Review. 43(1), 12-27.

Lombardi, \& Coley. (2017). Early Maternal Employment and Children 's Academic and Behavioral Skills in Australia and the United Kingdom. 1-19.

Lucas-Thompson, R. G., Lunkenheimer, E. S., Dumitrache, A. (2017). Associations Between Marital Conflict and Adolescent Conflict Appraisals, Stress Physiology, and Mental Health. Journal of Clinical Child and Adolescent Psychology: The Official Journal for the Society of Clinical Child and Adolescent Psychology, America. 46(3), 379-393. https://doi.org/10.1080/15374416.2015.1046179

Luo, Jia, Yue, Zhang, Lyu, \& Shi. (n.d.). Passive parenting and its association with early child development. Early. Child. Dev. Care, 78, 50-80.

Mensah, \& Kuranchie. (2013). Influence of Parenting Styles on the Social Development of Children. Acad. J. Interdiscip. Stud.

Mirzaee, Khadijeh, Ghadikolaee, S. O., \& Shakeri., M. T. (2015). Maternal Knowledge on Postpartum Care in Healthcare Centers of Mashhad, Iran in 2013.

Moffitt, Arseneault, Belsky, Dickson, Hancox, Harrington, \& Caspi. (2011). A gradient ofchildhood self-control predicts health, wealth, and public safety. Proceedings Ofthe National Academy OfSciences Ofthe United States OfAmerica, 108(7), 2693-2698. 
Nezhad. (2013). Analysis of Mothers Employment and its influence on children's' Training in Family". Current Research Journal of Biological Sciences, 5(1), 5-12.

Perna, L., Bolte, G., Mayrhofer, H., Spies, G., \& Mielck, A. (2010). The impact of the social environment on children's mental health in a prosperous city: an analysis with data from the city of Munich. BMC Public Health. 10(1), 199. https://doi.org/10.1186/1471-2458-10-199

Qi. (2017). A new isoflavone from the roots of Ficus auriculata. Natural Product Research. http://dx.doi.org/10.1080/14786419.2017.1329728

Raposa, E., Hammen, C., Brennan, P., \& Najman, J. (2014). The Long-Term Effects of Maternal Depression: Early Childhood Physical Health as a Pathway to Offspring Depression. Journal of Adolescent Health. 54(1), 88-93. https://doi.org/10.1016/j.jadohealth.2013.07.038

Ren, Hu, \& Song. (2019). Child routines mediate the relationship between parenting and socialemotional development in Chinese children. Child. Youth Serv. Rev. 98(1), 1-9.

Rinaldi, \& Howe. (2012). Mothers' and fathers' parenting styles and associations with toddlers' externalizing, internalizing, and adaptive behaviors. Early Childhood Research Quarterly, 27, 266-273.

Romano, Babchishin, Pagani, \& Kohen. (2010). School readiness and later achievement: Replication and extension using a nationwide Canadian survey. Developmental Psychology, 46(5), 9951007.

Saltal1, \& Arslan. (2012). Parent's attitudes as a predictor of preschoolers' social competence and introverted behavior, Elementary Education Online. 11(3), 729-737.

Sels, Ceulemans, Bulteel, \& Kuppens. (2016). Emotional Interdependence and Well-Being in Close Relationships.

Serbin, Hubert, Hastings, Stack, \& Schwartzman. (2014). The influence of parenting on early childhood health and health care utilization. Journal of Pediatric Psychology, 39(10), 11611174 .

Simkiss. (2013). Validation of the mothers object relations scale in 2-4 year old children and comparison with the chil-parent relationship scale. Helath and Quality of Life Outcomes.

Singh. (2018). Impact of Working Mothers on their Children 's Development. -3.

Tatli, \& Pirpir. (2015). Investigation of the effects of the relationships of children attending preschool education institutions with their teachers on their social skill levels. The Journal of Academic Social Science Studies, 31(1), 429-441.

Zarra, Kaisa, Noona, \& M, S. (2014). Social withdrawal in children moderates the association between parenting styles and the children's own socioemotional development. Journal of Child Psychology and Psychiatry and Allied Discipline, 55(11), 1260-1269.

Zheng, \& McMahon. (2019). Lability in Parental Warmth in Childhood: Antecedents and Early Adolescent Outcomes. J. Clin Child Adolecs, 1-13.

Zhong, Gao, Liu, Huang, \& Luo. (2019). Quantity-Quality Trade-Off and Early Childhood Development in Rural Family: Evidence from China's Guizhou Province. Int. . Environ. Res. Public Health, 16(1), 1307.

Zhong, He, Chen, \& Luo. (2020). Relationships between parenting skills and early childhood development in rural households in western China. International Journal of Environmental Research and Public Health, 17(5). 